University of Nebraska - Lincoln

DigitalCommons@University of Nebraska - Lincoln

Agronomy \& Horticulture -- Faculty Publications

Agronomy and Horticulture Department

2013

\title{
Enzyme activity in wheat breeding lines derived from matings of low polyphenol oxidase parents
}

\author{
Somrudee Nilthong \\ Mae Fah Luang University \\ Robert A. Graybosch \\ USDA-ARS, bob.graybosch@ars.usda.gov \\ P. Stephen Baenziger \\ University of Nebraska-Lincoln, pbaenziger1@unl.edu
}

Follow this and additional works at: https://digitalcommons.unl.edu/agronomyfacpub

Part of the Agricultural Science Commons, Agriculture Commons, Agronomy and Crop Sciences

Commons, Botany Commons, Horticulture Commons, Other Plant Sciences Commons, and the Plant

Biology Commons

Nilthong, Somrudee; Graybosch, Robert A.; and Baenziger, P. Stephen, "Enzyme activity in wheat breeding lines derived from matings of low polyphenol oxidase parents" (2013). Agronomy \& Horticulture -- Faculty Publications. 683.

https://digitalcommons.unl.edu/agronomyfacpub/683

This Article is brought to you for free and open access by the Agronomy and Horticulture Department at DigitalCommons@University of Nebraska - Lincoln. It has been accepted for inclusion in Agronomy \& Horticulture -Faculty Publications by an authorized administrator of DigitalCommons@University of Nebraska - Lincoln. 


\title{
Enzyme activity in wheat breeding lines derived from matings of low polyphenol oxidase parents
}

\author{
Somrudee Nilthong • R. A. Graybosch • \\ P. S. Baenziger
}

This article is a U.S. government work, and is not subject to copyright in the United States.

Received: 21 February 2012/ Accepted: 8 August 2012/Published online: 25 August 2012

(C) Springer Science+Business Media B.V. (outside the USA) 2012

\begin{abstract}
Polyphenol oxidase (PPO) in grain plays a major role in time-dependent discoloration of wheat (Triticum aestivum L.) products, especially fresh noodles. Breeding wheat cultivars with low or nil PPO activity can reduce undesirable product darkening. The low PPO line PI 117635 was crossed to two low PPO wheats, IDO580 and 'IDO377s', to determine whether matings between wheats with low levels of grain PPO would result in complementation, such that lines with still lower or nil PPO would be generated. Progeny in a population derived from PI 117635/ IDO580 displayed no variation in PPO activity. In the $\mathrm{F}_{3: 4}$ populations derived from PI 117635/IDO377s, and the reciprocal IDO377s/PI 117635, normal distributions of low to high PPO activity were observed. Fieldgrown populations $\left(\mathrm{F}_{3: 5} ; \mathrm{F}_{3: 6}\right)$ derived from IDO377s
\end{abstract}

S. Nilthong · P. S. Baenziger

Department of Agronomy and Horticulture,

University of Nebraska, Lincoln, NE 68583, USA

Present Address:

S. Nilthong

School of Science, Mae Fah Luang University,

333 Moo 1 Tambon Tasud, Muang District,

Chiang Rai 57100, Thailand

R. A. Graybosch ( $\square)$

USDA-ARS, University of Nebraska, 137 Keim, Lincoln,

NE 68583, USA

e-mail: bob.graybosch@ars.usda.gov crosses were analyzed for PPO activity and used to determine whether lines with nil PPO activity were generated. Of 239 lines, 154 were verified to have PPO activity that was not significantly different from the low PPO durum (Triticum turgidum var durum) cultivar 'Ben'. PCR analysis showed that the populations were fixed for a putative low PPO allele at Ppo-A1. Using markers for Ppo-D1, it was found that the average PPO activity of lines with $490 \mathrm{bp} \mathrm{PCR}$ fragments from PPO29 was significantly lower than that of lines with $560 \mathrm{bp}$ fragments from STS01. These results disagreed with that predicted from previous reports for markers for Ppo-Dl alleles. Thus, breeders should exercise caution when making selections using markers for alleles at Ppo-D1, as known markers might predict erroneous phenotypes and genotypes in some wheat backgrounds.

Keywords Triticum aestivum - Grain enzymes · Product discoloration $\cdot$ Complementation

\section{Introduction}

In Asia, over $40 \%$ of common wheat (Triticum aestivum L.) flour is used for making noodles (Hou 2001). Two popular types of Asian noodles are white noodles and yellow alkaline noodles. White noodles are made from soft wheat flour with low protein and salt contents. Yellow noodles contain alkaline salt, and are produced from hard wheat flour with higher 
protein content (Nagao 1996). Different types of noodles vary in firmness and texture, but consumer preference requires most noodle types to have a bright and creamy white color (Wang et al. 2009).

Polyphenol oxidase (PPO, EC 1.14.18.1) is a major cause of time-dependent discoloration in noodles, chapattis, and other wheat products (Baik et al. 1995; Miskelly 1996; Hatcher et al. 1999; Morris et al. 2000). PPO is a copper-containing enzyme involved in enzymatic browning using phenolic compounds as the primary substrates (Nicolas et al. 2003). PPOs catalyze two reactions: the hydroxylation of $o$-monophenol to $o$-diphenols (E.C. 1.14.18.1; monophenol monooxygenase, tyrosinase, or cresolase) and the dehydrogenation of $o$-diphenols to $o$-quinones (E.C. 1.10.32; diphenol oxygen oxidoreductase, diphenol oxidase, or catecholase) in the presence of oxygen. The quinones react with amines and thiol groups or undergo selfpolymerization to produce dark or brown products (Mayer and Harel 1979; Baik et al. 1994; Anderson and Morris 2001). Generally, PPO activity is located in the bran and more specifically in the aleurone layer of wheat kernels, both of which are mostly removed during the milling process (Sullivan 1964). Residual contamination by the bran layer after milling, however, is still sufficient to cause product discoloration (Rani et al. 2001). Developing wheat cultivars having genetically low or nil PPO activity is a current priority of many wheat breeding programs.

PPO genes have been studied in many plant species such as potato (Solanum tuberosum; Hunt et al. 1993), sugarcane (Saccharum officianrum L.; Bucheli et al. 1996), and tomato (Solanum lycopersicum; Thipypong et al. 1997) and PPO often is encoded by gene families (Sherman et al. 1995). In common wheat, three genes, Ppo-A1, Ppo-B1 and Ppo-D1, were described as expressing in developing kernels and may influence PPO activity in flour, and three additional genes express in non-kernel tissues (Demeke and Morris 2002; Jukanti et al. 2004). Beecher and Skinner (2011) recently identified three new PPO-encoding genes, Ppo-A2, Ppo-B2 and Ppo-D2, localized to the same chromosome arms as known kernel-expressing PPO genes.

Durum (Triticum turgidum var durum) wheat cultivars typically have very low or nil PPO activity, whereas common wheats vary in PPO activity (Kruger et al. 1994; Baik et al. 1995; Miskelly 1996). In hexaploid wheat, the $2 \mathrm{D}$ chromosome was associated with enhanced levels of kernel PPO activity (Anderson and Morris 2001) and in tetraploid wheat, which lacks the D genome, high PPO activity was mapped to the long arm of chromosome 2A (Simone et al. 2002; Raman et al. 2005). Jiménez and Dubcovsky (1999), using chromosome substitution lines from three cultivars into Chinese Spring, proposed that genes located on homoeologous group 2 of wheat chromosomes play a major role in PPO activity. QTL analysis showed that additional genes influencing PPO activity might be located on chromosomes 2A, 2B, 2D, 3D and 6B (Jiménez and Dubcovsky 1999; Demeke et al. 2001; Simone et al. 2002; Raman et al. 2005). Beecher and Skinner (2011) used real-time PCR analysis to demonstrate that Ppo-Ala, Ppo-A2b, Ppo-D1b and $P p o-D 2 b$ in the wheat cultivar 'Alpowa' were expressed to substantial levels in developing wheat kernels, whereas $P p o-B 1$ and $P$ po-B2 expression was not detected. The average contributions of Ppo-Ala and $P p o-A 2 b$ from the A genome were greater than expression of Ppo-D1b and Ppo-D2b from the D genome. This is in agreement with the results of Raman et al. (2005) who identified a major QTL controlling PPO activities on the long arm of chromosome 2A in a DH population derived from 'Chara' (medium-high PPO)/'WW2499' (low PPO). Baik et al. (1994) and Park et al. (1997) reported that PPO activity in common wheat is influenced by both genotype and environment.

DNA marker studies have attributed most of the variation in wheat PPO activity to alleles at Ppo-Al and Ppo-D1. Intra-locus sequenced-tagged site (STS) marker PPO18 was designed based on DNA sequences in Ppo-Al (Sun et al. 2005). PPO18 proved an efficient marker for Ppo-Al (He et al. 2007), amplifying two fragments, a $685 \mathrm{bp}$ PCR fragment in cultivars with high PPO activity (Ppo-Ala allele) and a 876 bp PCR fragment in cultivars with low PPO activity (Ppo-Alb allele) (Sun et al. 2005; He et al. 2007). Complementary dominant STS markers, PPO29 and STS01were developed based on the DNA sequences of the Ppo-Dl PPO gene on chromosome 2D (He et al. 2007; Wang et al. 2009). PPO29 reportedly amplified a 490 bp PCR fragment in cultivars with high PPO activity, indicating the presence of the Ppo-Dlb allele (He et al. 2007). STS01 amplified a 560 bp PCR fragment which corresponded to the Ppo-Dla allele in most cultivars with low PPO activity (Wang et al. 2008). 
In polyploid organisms such as wheat, a type of complementation can occur when lines carrying recessive alleles at independent loci are crossed, and resulting progeny display recessive or mutant phenotypes. Waxy (amylose-free) wheat is an example. Waxy wheats carry null alleles at loci, $w x-A 1$, $w x-B 1$, and $w x-D 1$, encoding isoforms of granule bound starch synthase (GBSS) (Nakamura et al. 1992; Graybosch 1998). The first waxy wheat was produced by crossing the $w x-D l$ single null line 'BaiHuo' and the $w x-A 1 / w x-B 1$ double null line 'Kanto 107 ' resulting in progeny that lacked all isoforms of GBSS (Nakamura et al. 1992) and also lacked endosperm starch amylose. The goal of the present study was to determine whether crosses between cultivars with low phenotypic levels of grain PPO could produce a similar type of complementation, allowing lines with lower or nil PPO to be generated. Secondly, the relationship between low grain PPO and previously described DNA markers for PPO activity was investigated.

\section{Materials and methods}

\section{Plant materials}

Hard white spring wheat accession PI 117635 (low PPO) was crossed to two low PPO spring wheats IDO580 and 'IDO377s' from Idaho. For purposes of this study, lines were considered "low" when PPO values (see below) were consistently lower than the medium-low hard white winter wheat control cultivar 'Anton' (Graybosch et al. 2011). PI 117635 is an Australian white spring wheat, originating in the 1930's, derived from the cross: Kenya/Florence// Dundee. IDO580 (Souza et al. 2005) is a semi-dwarf germplasm line with low levels of grain PPO. IDO580 was derived from the cross, 'Cadoux' (PI 591905)// 'Maya 74'/M2. M2 is a synthetic hexaploid wheat developed at CIMMYT by crossing 'Ruff' durum with CIMMYT Triticum tauschii (Coss.) Schmalh. germplasm \#112, previously found to have very low levels of seed PPO activity. IDO377s (PI 591045), a hard white spring wheat cultivar (Souza et al. 1997), has been cultivated in the Pacific Northwest region of the USA. IDO377s was derived from the cross 'Chova'/ 59Ab10293-5. Chova has the pedigree: 'Gallo'/'Yecora' reselection/3/'Aurora'//'Kalyansona'/'Bluebird'. The pedigree of 59Ab10293-5 is 'Norin 10'/"Brevor'// 'Baart'/'Onas'.

Five hundred heads were selected at random from the $\mathrm{F}_{3}$ populations of these crosses and sown at Yuma, AZ in the spring of 2008. Heads were snapped, threshed individually, and seed planted in the field as $\mathrm{F}_{3}$ - derived $\mathrm{F}_{4}$ single plant progeny rows in fall of 2008 at Yuma, AZ. The $\mathrm{F}_{3: 5}$ generation was harvested from Yuma, AZ in early spring 2009 and the $\mathrm{F}_{3: 6}$ generation was immediately planted at Corvallis, OR, also as single rows. Seven cultivars, 'Ben' (durum wheat), and the common wheats 'Express', IDO377s, 'DO580, 'Jubilee', PI 117635, and 'Seaspray' were included as controls with the 2009 experiments. An augmented design was used with checks replicated a minimum of three times, and experimental lines un-replicated at each location. Means for each line were determined by averaging data from the two locations $\left(\mathrm{F}_{4}\right.$ and $\mathrm{F}_{5}$ generations).

Yuma, AZ (32.69 Lat. -114.62 Long.) in southwestern USA is characterized by a desert climate, with an average annual precipitation of $7.5 \mathrm{~cm}$. Wheat production always requires irrigation. Corvallis, OR (44.56 Lat. -123.26 Long.) is in the Pacific Northwest, with a mild climate and average annual precipitation of over $100 \mathrm{~cm}$. Wheat production is rainfed.

\section{Measurement of PPO activity}

PPO activity in wheat grains was measured as per Anderson and Morris (2001). Five whole seeds were weighed. A $1.5-\mathrm{ml}$ aliquot of $10 \mathrm{mM}$ L-DOPA (3, 4-dihydroxyphenylalanine, Sigma-Aldrich Co., St. Louis, MO) as substrate in $50 \mathrm{mM}$ MOPS [3-( $N$-morpholino) propane sulfonic acid, SigmaAldrich Co., St. Louis, MO] buffer, pH 6.5, was added to a $2 \mathrm{ml}$ microcentrifuge tube containing the five seeds. The tubes were placed on a Labquake Rotisserie Shaker from Barnstead/Thermolyne (Dubuque, IA) and rotated at $8 \mathrm{rpm}$ for $1 \mathrm{~h}$ at room temperature to allow the reaction to occur. Absorbance was measured on a $250 \mu \mathrm{l}$ aliquot of the incubated solution at $475 \mathrm{~nm}$ using a Shimadzu BioSpec-1601 spectrophotometer (Shimadzu Corporation, Columbia, MD). Seeds from the cultivars 'Arapahoe' (red winter wheat with high PPO activity), Anton (white winter wheat with low to moderate PPO activity), and Ben (spring durum with low PPO activity) were included with every run as experimental laboratory 
controls to measure consistency of the protocol. Each reaction was run in duplicate. The L-DOPA solution was freshly made each day.

\section{DNA isolation and STS analysis}

Genomic DNA was isolated from young leaf tissues of a minimum of eight plants using a CTAB (cetyltrimethyl ammonium bromide) method modified from Doyle and Doyle (1987). Sequence tagged site (STS) markers PPO18, PPO29, and STS01 were synthesized by Invitrogen Co. (Carlsbad, CA) using primers presented in $\mathrm{He}$ et al. (2007) and Wang et al. (2004). PCR were performed in total volumes of $25-\mu 1$ containing $100 \mathrm{ng}$ of genomic DNA, $10 \mathrm{mM}$ Tris- $\mathrm{HCl}, 1.5 \mathrm{mM} \mathrm{MgCl}_{2}, 50-\mathrm{mM} \mathrm{KCl}$ buffer, $0.2 \mathrm{mM}$ of each dNTP, $0.4 \mu \mathrm{M}$ of each oligonucleotide primer, 0.028 unit of Taq DNA polymerase (Roach, Mannheim, Germany) in a Bio-Rad DNA Engine Peltier Thermal Cycler. The thermocycling program was $95{ }^{\circ} \mathrm{C}$ for $5 \mathrm{~min}$, followed by 40 cycles of touchdown PCR at $95{ }^{\circ} \mathrm{C}$ for $1 \mathrm{~min}, 56-50{ }^{\circ} \mathrm{C}$ for $1.5 \mathrm{~min}$ for PPO18 or $62-57{ }^{\circ} \mathrm{C}$ for $1 \mathrm{~min}$ for STS01, $72{ }^{\circ} \mathrm{C}$ for $2 \mathrm{~min}$, with a final extension of $72{ }^{\circ} \mathrm{C}$ for 8 min. PPO29 PCR amplification was performed at $95{ }^{\circ} \mathrm{C}$ for $5 \mathrm{~min}$, followed by 36 cycles of $94{ }^{\circ} \mathrm{C}$ for $1 \mathrm{~min}, 69.6{ }^{\circ} \mathrm{C}$ for $1 \mathrm{~min}, 72{ }^{\circ} \mathrm{C}$ for $1 \mathrm{~min}$, and final extension of $72{ }^{\circ} \mathrm{C}$ for $8 \mathrm{~min}$. Amplified PCR fragments were separated on $1.5 \%$ agarose gels, stained with ethidium bromide, and visualized using UV light.

Statistical analysis

All statistical computations were made using SAS computer packages version 9.2 for Windows (SAS Institute Inc., Cary, NC, USA). Analysis of variance (Proc GLM) was used to test for significant differences among environments, genotypes, and genotypes nested within environments using appropriate error terms for an augmented design with replicated check cultivars. Transgressive segregation among lines and parents was determined using a Least Significant Difference procedure with $\alpha=0.05$. Pairwise comparisions ( $t$-test) were used at $\alpha=0.05$ to compare PPO levels of lines with Ben. Based on PCR results, genotypes were designated BA (Ppo-Alb/Ppo-D1b); BH (PpoAlb/Ppo-Dla-Dlb); BB (Ppo-Alb/Ppo-Dla); Ben; Express; IDO377s; IDO580; Jubilee; PI 1176351; and Seaspray. PROC UNIVARIATE was used for testing normality. Chi-squared analysis was used to test segregation ratios of DNA markers. To determine the relationship between kernel PPO activity (Optical density = OD) and kernel PPO activity per gram seed weight $(\mathrm{OD} / \mathrm{g})$, Pearson correlations were calculated using PROC CORR. Both actual and log transformed data were analyzed. A log transformation was used to normalize the data and designated as ODT. Both the actual and transformed data showed the same results. Therefore, the tables in this study include both actual and transformed values, and, since the results were the same, only the actual values will be discussed.

\section{Results and discussion}

Average PPO activities of the laboratory control cultivars were: Arapahoe, $1.032 \pm 0.018 \mathrm{AU}$; Anton, $0.376 \pm 0.015 \mathrm{AU}$ and Ben, $0.075 \pm 0.003 \mathrm{AU}$ $(n=27)$. Daily fluctuation was proportional to mean values, with little fluctuation observed in Ben (Fig. 1). Relative rankings of control samples never changed.

The 2008 Yuma field-grown $\mathrm{F}_{4}$ populations derived from crosses PI 117635/IDO580 and PI 117635/ IDO377s were analyzed for PPO activity. In the PI 117635/IDO580 cross, little variation in PPO level (population mean $=0.097 \pm 0.004$ AU; Fig. 2) occurred among the progeny, even though marker data indicated segregation of different alleles at Ppo-D1 (marker data not shown). A wider range in PPO activity was observed in the populations derived from PI 117635 and IDO377s. The observed ranges in PPO activity were $0.142-0.502$ AU for PI 117635/IDO377s

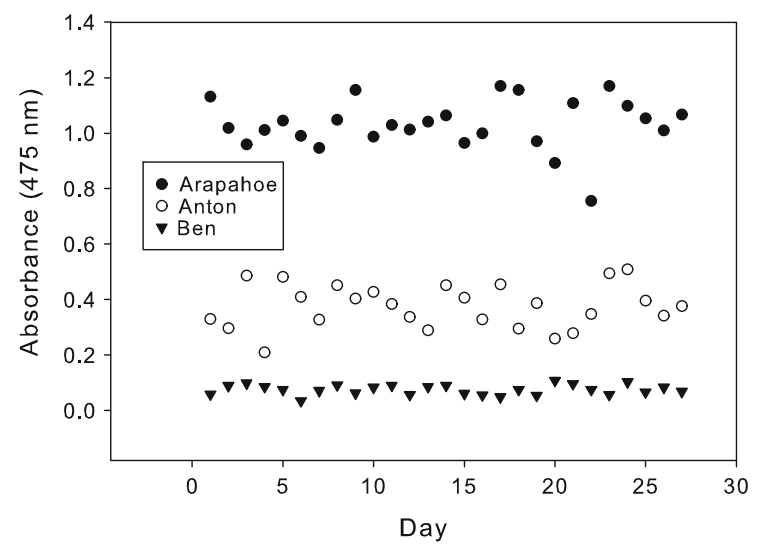

Fig. 1 Observed daily PPO activity of laboratory experimental controls 
and 0.111-0.620 AU for IDO377s/PI 117635. Mean $2008 \mathrm{~F}_{4}$ PPO activity for the lines derived from PI $117635 /$ IDO377s was $0.272 \pm 0.008 \mathrm{AU}(n=124)$ and the reciprocal cross IDO377s/PI 117635, $0.312 \pm$ $0.011 \mathrm{AU}(n=115)$. The range of values indicated that both parents contain alleles associated with higher and lower PPO activity, even though both parents were first selected for low PPO activity. The PI 117635/IDO377s population had slightly more lines with low $(\mathrm{AU}<0.30)$ PPO activities and the distribution was not normal $(P=0.02$; Fig. $3 a)$, whereas the reciprocal IDO377s/PI 117635 population had a normal distribution $(P=0.65$; Fig. $3 b)$.

Of the $239 \mathrm{~F}_{3}$-derived lines from the crosses between PI 117635 and IDO377s, 119 lines amplified a 490 bp PCR fragment (A pattern) with the PPO29 marker. STS01 amplified a 560 bp PCR fragment (B pattern) in 98 lines. The remaining 22 lines amplified both 490 bp and 560 bp PCR fragments (H pattern) with markers PPO29 and STS01 and were considered heterozygous. The expected proportions of $\mathrm{F}_{3: 5}$ genotypes are 3A: 2H: 3B. The Chi-squared value was 34.26 , over the critical value $\left(\chi^{2} 0.05,2 \mathrm{df}=5.99\right)$, indicating that the segregation deviated from the expected $3 \mathrm{~A}: 2 \mathrm{H}: 3 \mathrm{~B}$ ratio. This deviation arose from a deficiency of $\mathrm{H}$ individuals. The $\mathrm{A}$ and $\mathrm{B}$ classes fit the expected $1: 1$ ratio $\left(\chi^{2}=2.03 ; P=0.154\right)$. The PPO18 marker amplified the same $865 \mathrm{bp}$ fragment from all of 239 lines, indicating all lines were fixed for the putative low PPO allele at Ppo-A1. From the marker screening, the genotypes of progeny were assigned to three classes: Ppo-Alb/Ppo-D1b designated as BA; Ppo-Alb/Ppo-D1a-D1b designated as

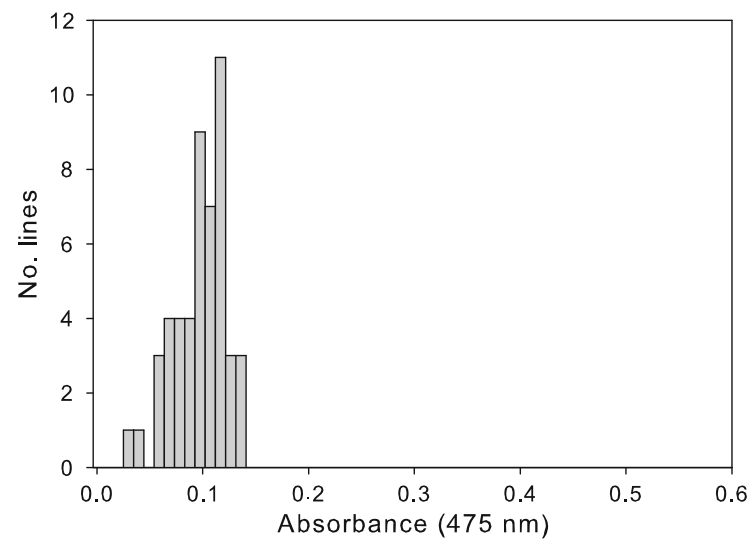

Fig. 2 Distribution of mean PPO activity in the population derived from IDO580/PI 117635 grown in Yuma AZ in 2008
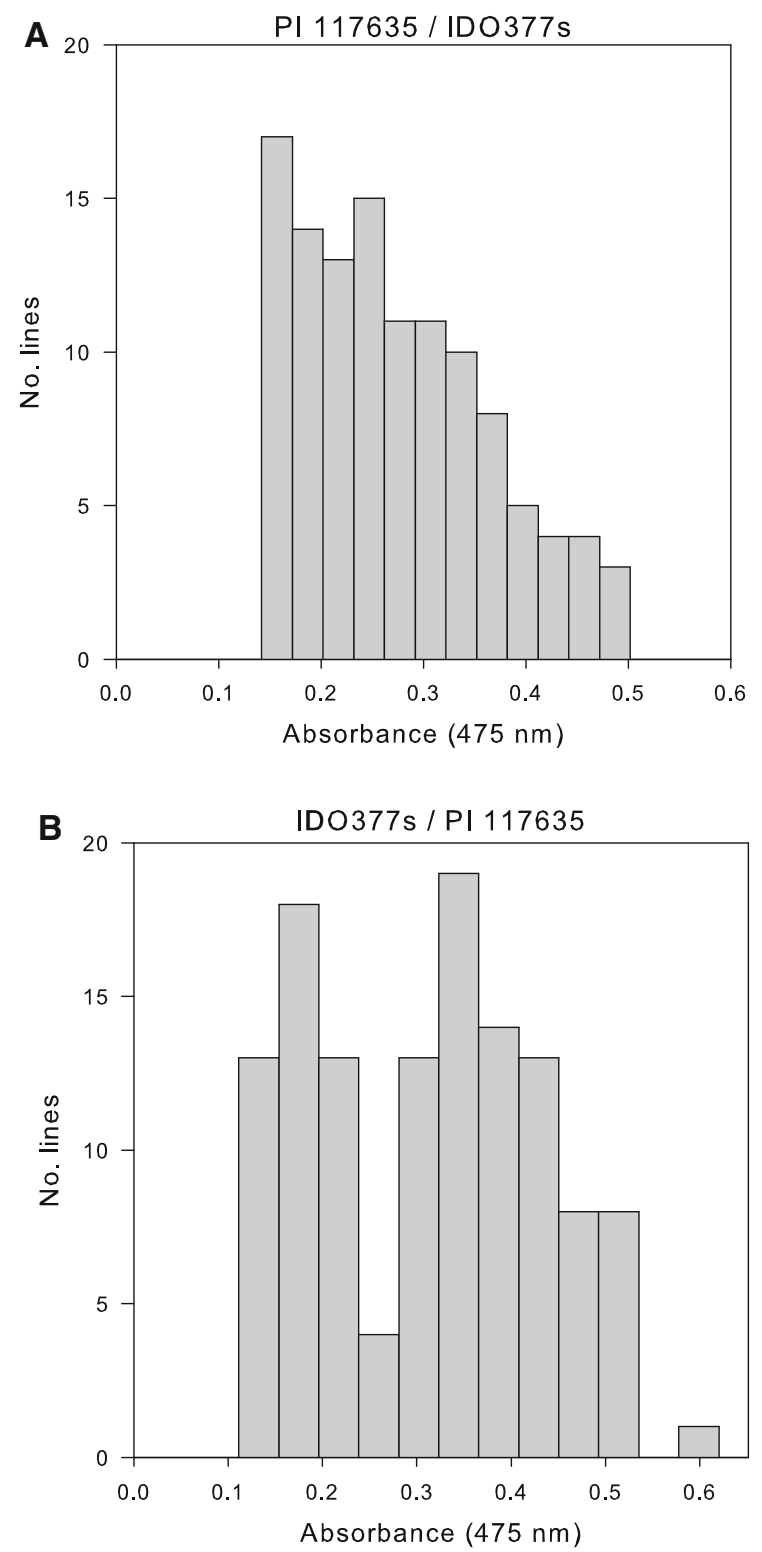

Fig. 3 Distribution of mean PPO activity in the populations derived from PI 117635/IDO377s (a) and IDO377s/PI 117635 (b) grown in Yuma AZ in 2008

BH; Ppo-Alb/Ppo-Dla designated as BB. PI 117635 was identified as BA (Ppo-Alb/Ppo-D1b) and IDO377s confirmed as BB (Ppo-Alb/Ppo-Dla).

Analysis of variance of Yuma09 and OR09 grown materials $\left(\mathrm{F}_{4}\right.$ and $\mathrm{F}_{5}$ generations) showed highly significant differences among environments, genotypes (PPO alleles) and environment by genotype interaction (Table 1), suggesting a differential effect of environment on expression of grain PPO activity, 
Table 1 Mean squares from analysis of variance of kernel PPO activity within the PI 117635/IDO377s population grown in Yuma and Oregon in 2009

\begin{tabular}{|c|c|c|c|c|c|}
\hline \multirow{2}{*}{$\begin{array}{l}\text { Source of } \\
\text { variation }\end{array}$} & \multirow[t]{2}{*}{ df } & \multicolumn{4}{|c|}{ Mean square } \\
\hline & & $\begin{array}{l}\mathrm{PPO} \\
\text { activity } \\
(\mathrm{OD})^{\mathrm{a}}\end{array}$ & $\begin{array}{l}\text { PPO } \\
\text { activity } \\
(\mathrm{OD} / \\
\mathrm{g})^{\mathrm{b}}\end{array}$ & $\begin{array}{l}\text { PPO } \\
\text { activity } \\
(\mathrm{ODT})^{\mathrm{c}}\end{array}$ & $\begin{array}{l}\text { PPO } \\
\text { activity } \\
(\text { ODT/ } \\
\text { g })^{\text {d }}\end{array}$ \\
\hline Environments & 1 & $0.2291 *$ & $2.7395^{*}$ & $0.1660 *$ & $0.8003 *$ \\
\hline Genotypes & 9 & $0.0718 *$ & $2.6917 *$ & $0.0538 *$ & $0.9186 *$ \\
\hline $\begin{array}{l}\text { Environment } \\
\mathrm{x} \text { genotype }\end{array}$ & 9 & $0.0131 *$ & $0.2458^{*}$ & $0.0084 *$ & $0.0430 *$ \\
\hline Error & 510 & 0.0021 & 0.0593 & 0.0015 & 0.0181 \\
\hline
\end{tabular}

\footnotetext{
* Significant at $P=0.05$

a Polyphenol oxidase activity

b Polyphenol oxidase activity on a per gram of kernel

c $\log$ transformation of PPO activity

${ }^{d} \log$ transformation of PPO activity on a per gram of kernel
}

confirming previously observed environmental effects (Park et al. 1997; McCaig et al. 1999; Demeke et al. 2001). Identical results (Table 1) were obtained using $\mathrm{OD}$ and $\mathrm{OD} / \mathrm{g}$. Pearson correlation coefficients were calculated separately for each environment and for combined environments, in order to determine possible relations between $\mathrm{OD}$ and $\mathrm{OD} / \mathrm{g}$. $\mathrm{R}$ values for this correlation using Yuma09, OR09 and the combined environments were $0.93,0.98$ and 0.95 , indicating OD was highly correlated with $\mathrm{OD} / \mathrm{g}$ in all cases $(P<0.0001)$. Weighing seed before assaying PPO activity is therefore not necessary, allowing breeding programs to evaluate more materials with less labor.

The respective Yuma09 and OR09 experimental means for PPO activity were $0.183 \pm 0.004 \mathrm{AU}$ and $0.099 \pm 0.003 \mathrm{AU}(n=239)$, lower than the values observed for initial 2008 observations (Table 2). The minimum and maximum PPO activities of experimental lines were 0.091 and 0.373 AU for Yuma09 and 0.025 and 0.247 AU for OR09. The mean PPO activities of the parents were $0.079 \pm 0.012 \mathrm{AU}$ for PI 117635 and $0.132 \pm 0.009$ AU for IDO377s, whereas that of Ben durum was $0.053 \pm 0.004$ (Table 2). The PPO activity distribution of the PI 117635/IDO377s population was normal $(P=0.41)$ whereas the reciprocal IDO377s/PI 117635 population was not $(P=0.01)$ (Fig. 4a, b). In both populations, some progenies exhibited significantly higher PPO activities than those of either parent (Table 2) confirming the presence of transgressive segregation within the population. Transgressive segregation arises from complementary gene action (the occurrence of combinations of alleles from both parents affecting a trait in the same direction) (Rieseberg et al. 2003). Of the inbred lines, 154 had PPO activities not significantly different from that of Ben durum when assessed by $t$-tests $\left(\mathrm{LSD}_{\alpha}=0.05\right)$. It is now clear that variation exists among common wheat lines to derive materials with PPO activities as low as Ben. PPO activity of IDO580 was as low as Ben; however, it was derived from a synthetic population, with genes from T. tauschii. The materials derived from IDO377s/PI

Table 2 Average kernel PPO activities of genotypes with different PCR fragments amplified by markers PPO18, PPO29 and STS01 within PI 117635/IDO377s population

\begin{tabular}{|c|c|c|c|c|c|}
\hline Genotype & $\mathrm{N}$ & $\begin{array}{l}(\mathrm{OD}) \\
\text { Mean } \pm \mathrm{SE}\end{array}$ & $\begin{array}{l}(\mathrm{OD} / \mathrm{g}) \\
\text { Mean } \pm \mathrm{SE}\end{array}$ & $\begin{array}{l}(\mathrm{ODT}) \\
\text { Mean } \pm \mathrm{SE}\end{array}$ & $\begin{array}{l}(\mathrm{ODT} / \mathrm{g}) \\
\text { Mean } \pm \mathrm{SE}\end{array}$ \\
\hline BA & 238 & $0.113 \pm 0.004$ & $0.536 \pm 0.017$ & $0.106 \pm 0.003$ & $0.416 \pm 0.010$ \\
\hline $\mathrm{BH}$ & 44 & $0.151 \pm 0.009$ & $0.753 \pm 0.038$ & $0.140 \pm 0.008$ & $0.551 \pm 0.022$ \\
\hline $\mathrm{BB}$ & 194 & $0.174 \pm 0.005$ & $0.938 \pm 0.020$ & $0.159 \pm 0.004$ & $0.652 \pm 0.010$ \\
\hline Ben & 8 & $0.053 \pm 0.004$ & $0.254 \pm 0.014$ & $0.051 \pm 0.004$ & $0.226 \pm 0.011$ \\
\hline Express & 8 & $0.249 \pm 0.061$ & $1.264 \pm 0.275$ & $0.214 \pm 0.047$ & $0.770 \pm 0.113$ \\
\hline IDO377s (BB) & 8 & $0.132 \pm 0.009$ & $0.872 \pm 0.056$ & $0.124 \pm 0.008$ & $0.624 \pm 0.030$ \\
\hline IDO580 & 7 & $0.059 \pm 0.010$ & $0.316 \pm 0.046$ & $0.057 \pm 0.010$ & $0.271 \pm 0.036$ \\
\hline Jubilee & 8 & $0.157 \pm 0.030$ & $0.810 \pm 0.106$ & $0.144 \pm 0.026$ & $0.581 \pm 0.059$ \\
\hline PI 117635 (BA) & 9 & $0.079 \pm 0.012$ & $0.342 \pm 0.033$ & $0.073 \pm 0.011$ & $0.292 \pm 0.024$ \\
\hline Seaspray & 6 & $0.180 \pm 0.034$ & $0.872 \pm 0.103$ & $0.163 \pm 0.029$ & $0.620 \pm 0.055$ \\
\hline
\end{tabular}

$\mathrm{BA}=$ Ppo-A1b/Ppo-D1b, $\mathrm{BH}=$ Ppo-Alb/Ppo-Dla, D1b, BB =Ppo-Alb/Ppo-Dla 

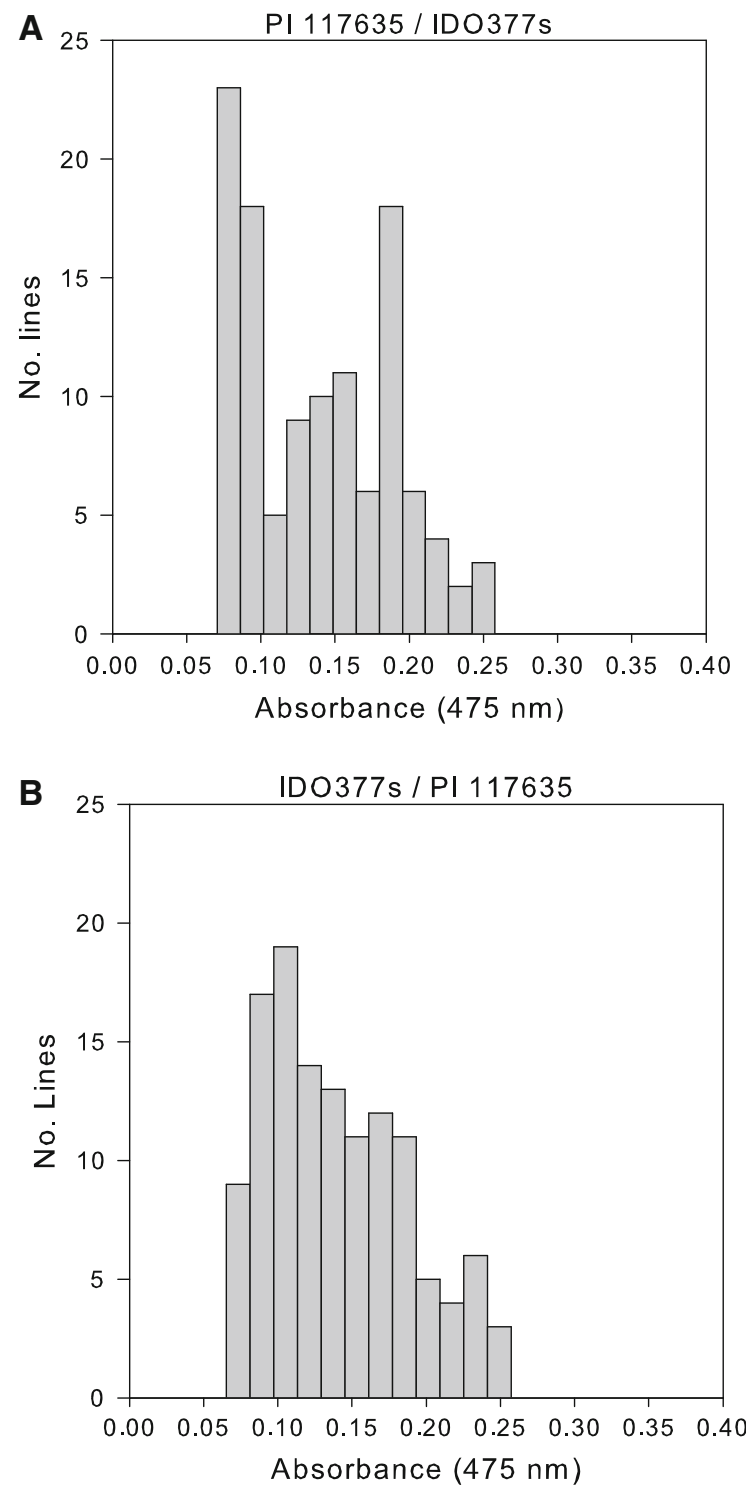

Fig. 4 Distribution of mean kernel PPO activity in populations derived from PI 117635/IDO377s (a) and IDO377s/PI 117635 (b) grown in Yuma, AZ and Corvallis, OR in 2009. Mean values: Ben durum, 0.0.053; IDO377s, 0.132; PI 117635, 0.079

117635 only have genes from common wheats. Such sources of low PPO within the common wheat gene pool might ultimately prove more useful in breeding programs.

The average kernel PPO activities of the tested genotypes were: Ppo-A1b/Ppo-D1b (BA) 0.11 AU; Ppo-A1b/Ppo-Dla-D1b (BH) 0.15 AU; and Ppo-Alb/ Ppo-Dla (BB) 0.17 AU (Table 2). The average PPO activity of lines amplifying the $490 \mathrm{bp}$ PPO29 fragment was significantly lower than that of the lines with positive STS01 reactions (560 bp PCR fragments). However, this result does not agree with earlier reports for the STS01 and PPO29 markers, in which STS01 was a dominant marker for low PPO activity, and amplified a $560 \mathrm{bp}$ fragment in most low PPO cultivars (Wang et al. 2008), whereas PPO29 amplified a 490 bp PCR fragment in most high PPO cultivars (He et al. 2007). The Ppo-Alb/Ppo-Dlb (BA) genotype gave the lowest PPO activity and it was significantly lower $(P<0.05)$ than the Ppo-A1b/Ppo-Dla (BB) and Ppo-A1b/Ppo-Dla-Dlb (BH) genotypes. All lines produced a $876 \mathrm{bp}$ fragment from PPO18, indicating fixation of the low allele at Ppo-A1. All tested genotypes, however showed low levels of PPO activity when compared with the check cultivars.

Chromosome 2A was previously implicated as the site of major genes affecting kernel PPO activity (Raman et al. 2007). Subsequently, Beecher and Skinner (2011) identified and quantified expression levels for all PPO genes relevant to wheat quality and found that the A genome contributed greater grain PPO expression than the D genome; the A genome contributed more than $80 \%$ of the PPO gene transcripts present in developing seeds. This is in agreement with Martin et al. (2011) who found both the Ppo-Al and Ppo-Dl loci affected the levels of grain PPO activity $(P<0.01)$, but the effect for $P p o-A l$ was larger than that for $P$ po-DI. It is possible that in the presence of the low Ppo-Alb allele, as in the present study, the allelic status at Ppo-DI is irrelevant, especially considering the findings of Beecher and Skinner (2011) that this locus contributes little to overall PPO activity. Supporting this view is the lack of PPO variation observed for the progeny of PI 117635/IDO580, even though there was segregation for Ppo-Dl allelic markers. Additional genes encoding active PPO enzymes might also have influenced the results. While most previous work concentrated on the effects of alleles at Ppo-Al and Ppo-D1 Beecher et al. (2012) demonstrated the presence of additional PPO-encoding loci designated Ppo-A2, Ppo-B2, and Ppo-D2. In a segregating population derived from the cross 'Louise $\times$ Penawawa', variation in kernel PPO activity was significantly associated with markers closely linked to both Ppo-B2, and Ppo-D2. As these loci were not investigated in the present study, it is possible that segregation for functional alleles at one or more of these 
newly described loci confounded the effects of the Ppo-D1 alleles studied herein.

In conclusion, crosses between common wheat low PPO lines produced progeny with levels of PPO activity not significantly different from Ben durum. Our study showed that the populations were fixed for the low allele at Ppo-Alb, yet the PI 117635/IDO580 population showed no variation in PPO activity in the presence of segregation for Ppo-Dl alleles, and, in the PI 117635/IDO377s populations, the results were contrary to those previously predicted for Ppo-D1 alleles. This last observation suggests that a rare recombination event might have occurred within the Ppo-D1 locus, between the sites of primer binding and the sequences coding the active site of the enzyme. These results indicate that breeders could ignore variation at $P p o-D 1$, as most of the activity arises from Ppo-A1. Furthermore, markers for Ppo-D1 alleles might predict erroneous phenotypes and genotypes in some backgrounds and lineages. In addition, both genotypic and genotype $\times$ environment effects modulate the expression of PPO activity.

\section{References}

Anderson JV, Morris CF (2001) An improved whole-seed assay for screening wheat germplasm for polyphenol oxidase activity. Crop Sci 41:1697-1705

Baik BK, Czuchajowsa Z, Pomeranz Y (1994) Comparison of polyphenol oxidase activity in wheat and flours from Australian and US cultivars. J Cereal Sci 19:291-296

Baik BK, Czuchajowska Z, Pomeranz Y (1995) Discoloration of dough for oriental noodles. Cereal Chem 72:198-205

Beecher BS, Skinner D (2011) Molecular cloning and expression analysis of multiple polyphenol oxidase genes in developing wheat (Triticum aestivum) kernels. J Cereal Sci 53:371-378

Beecher BS, Carter AH, See DR (2012) Genetic mapping of a new family of seed-expressed polyphenol oxidase genes in wheat (Triticum aestivum L.). Theor Appl Genet 124:1463-1473

Bucheli CS, Dry IB, Robinson SM (1996) Isolation of a fulllength cDNA encoding polyphenol oxidase from sugarcane, a C4 grass. Plant Mol Biol 31:1233-1238

Demeke T, Morris CF (2002) Molecular characterization of wheat polyphenol oxidase (PPO). Theor Appl Genet 104:813-818

Demeke T, Morris CF, Campbell KG, King GE, Anderson JA, Chang HG (2001) Wheat polyphenol oxidase distribution and genetic mapping in three inbred line populations. Crop Sci 41:1750-1757

Doyle JJ, Doyle JL (1987) A rapid DNA isolation procedure for small quantities of fresh leaf tissue. Phytochem Bull 19:11-15
Graybosch RA (1998) Waxy wheats: origin, properties, and prospects. Trends Food Sci Technol 9:135-142

Graybosch RA, Peterson CJ, Baenziger PS, Baltensperger DD, Nelson LA, Jin Y, Kolmer J, Seabourn B, Beecher B (2011) Registration of 'Anton' hard red winter wheat. J Plant Regist 5:1-6

Hatcher DW, Symons SJ, Kruger JE (1999) Measurement of time-dependent appearance of discolored sports in alkaline noodles by image analysis. Cereal Chem 76:189-194

He XY, He ZH, Zhang LP, Sun DJ, Morris CF, Fuerst EP, Xia XC (2007) Allelic variation of polyphenol oxidase (PPO) genes located on chromosomes $2 \mathrm{~A}$ and $2 \mathrm{D}$ and development of functional markers for the PPO genes in common wheat. Theor Appl Genet 115:47-58

Hou G (2001) Oriental noodles adv food. Nutr Res 43:141-193

Hunt MD, Eannetta NT, Yu H, Newman SM, Steffens JC (1993) cDNA cloning and expression of potato polyphenol oxidase. Plant Mol Biol 21:59-68

Jiménez M, Dubcovsky J (1999) Chromosome location of genes affecting polyphenol oxidase activity in seeds of common and durum wheat. Plant Breed 118:395-398

Jukanti AK, Bruckner PL, Fischer AM (2004) Evaluation of wheat polyphenol oxidase genes. Cereal Chem 81:481-485

Kruger JE, Hatcher DW, DePauw R (1994) A whole seed assay for polyphenol oxidase in Canadian prairie spring wheats and its usefulness as a measure of noodle darkening. Cereal Chem 71:324-326

Martin JM, Berg JE, Hofer P, Kephart KD, Nash D, Bruckner PL (2011) Allelic variation of polyphenol oxidase genes impacts on Chinese raw noodle color. J Cereal Sci 54: 387-394

Mayer AM, Harel E (1979) Polyphenol oxidases in plants. Phytochemistry 18:193-215

McCaig TN, Fenn DYK, Knox RE, DePauw RM, Clarke JM, McLeod JG (1999) Measuring polyphenol oxidase activity in a wheat breeding program. Can J Plant Sci 79:507514

Miskelly DM (1996) The use of alkali for noodle processing. In: Kruger JE (ed) Pasta and noodle technology. American Association of Cereal Chemists, Inc., St. Paul, pp 227-272

Morris CF, Jeffers HC, Engle DA (2000) Effect of processing, formula and measurement variables on alkaline noodle color-toward an optimized laboratory system. Cereal Chem 77:77-85

Nagao S (1996) Processing technology of noodle products in Japan. In: Kruger JE, Matsuo, RB, Dick, JW (eds) Pasta and noodle technology. American Assoc Cereal Chemists, St. Paul, pp 169-194

Nakamura T, Yamamori M, Hidaka S, Hoshino T (1992) Expression of HMW Wx protein in Japanese common wheat (Triticum aestivum L.) cultivars in Japan. Jpn J Breed 42:681-685

Nicolas J, Billaud C, Rouet-Mayer MA, Philippon J (2003) Enzymatic browning. In: Caballero B, Trugo L, Finglas PM (eds) Encyclopaedia of food science, food technology and nutrition, 2nd edn, vol 1. Academic Press, London, pp 678-686

Park WJ, Shelton DR, Peterson CJ, Martin TJ, Kachman SD, Wehling RL (1997) Variation in polyphenol oxidase activity and quality characteristics among hard white wheat and hard red winter wheat samples. Cereal Chem 74:7-11 
Raman R, Raman H, Johnstone K, Lisle D, Smith A, Martin P, Allen H (2005) Genetic and in silico comparative mapping of the polyphenol oxidase gene in bread wheat (Triticum aestivum L.). Funct Integr Genomics 5:185-200

Raman R, Raman H, Martin P (2007) Functional gene markers for polyphenol oxidase locus in bread wheat (Triticum aestivum L.). Mol Breed 19:315-328

Rani KU, Rao P, Leelavathi JS, Rao HP (2001) Distribution of enzymes in wheat flourmill streams. J Cereal Sci 34:233242

Rieseberg LH, Widmer A, Arntz AM, Burke JM (2003) The genetic architecture necessary for trangressive segregation is common in both natural and domesticated populations. Phil Trans Roy Soc Lond B 358(1141-1):147

Sherman TD, Gardeur TL, Lax AR (1995) Implications of the phylogenetic distribution of polyphenol oxidase in plants. In: Lee CY, Whitaker JR (eds) Enzymatic browning and its prevention, ACS Symposium series 600. American Chemical Society, Washington, DC, pp 103-119

Simone R, Pasqualone A, Clodoveo LM, Blanco A (2002) Genetic mapping of polyphenol oxidase in tetraploid wheat. Cell Mol Biol Lett 7:763-769

Souza EJ, Windes JM, Guy SO, Robertson L, Sunderman DW, O'Brien K (1997) Registration of 'Idaho 377 s' wheat. Crop Sci 37:1393
Souza EJ, Guttieri MJ, Udall JA (2005) Registration of 'IDO580' spring wheat germplasm. Crop Sci 42:1746

Sullivan B (1964) Oxidizing enzyme systems of wheat and flour. In: Anderson JA (ed) Enzymes and their role in wheat technology. Interscience, New York, p 215

Sun DJ, He ZH, Xia XC, Zhang LP, Morris CF, Appels R, Ma WJ, Wang H (2005) A novel STS marker for polyphenol oxidase activity in bread wheat. Mol Breed 16:209-218

Thipypong P, Joel DM, Steffens JC (1997) Differential expression and turnover of the tomato polyphenol oxidase gene family during vegetative and reproductive development. Plant Physiol 113:707-718

Wang SC, Basten CJ, Zeng ZB (2004) Windows QTL cartographer 2.0: analyzing genetic agriculture of quantitative traits. http://statgen.ncsu.edu/qtlcart/WQTLCart.htm. Accessed 21 Aug 2012

Wang XB, Ma CX, He KQ, Si HQ, Zhang YL (2008) Development and application of a STS marker for grain PPO gene located on chromosome 2D in common wheat. Scientia Agric Sin 39:1583-1590

Wang XB, Ma CX, Si HQ, Qiao YQ, Chang C, He XF, Xia YX (2009) Gene markers for grain polyphenol oxidase activity in common wheat. Mol Breed 23:163-170 